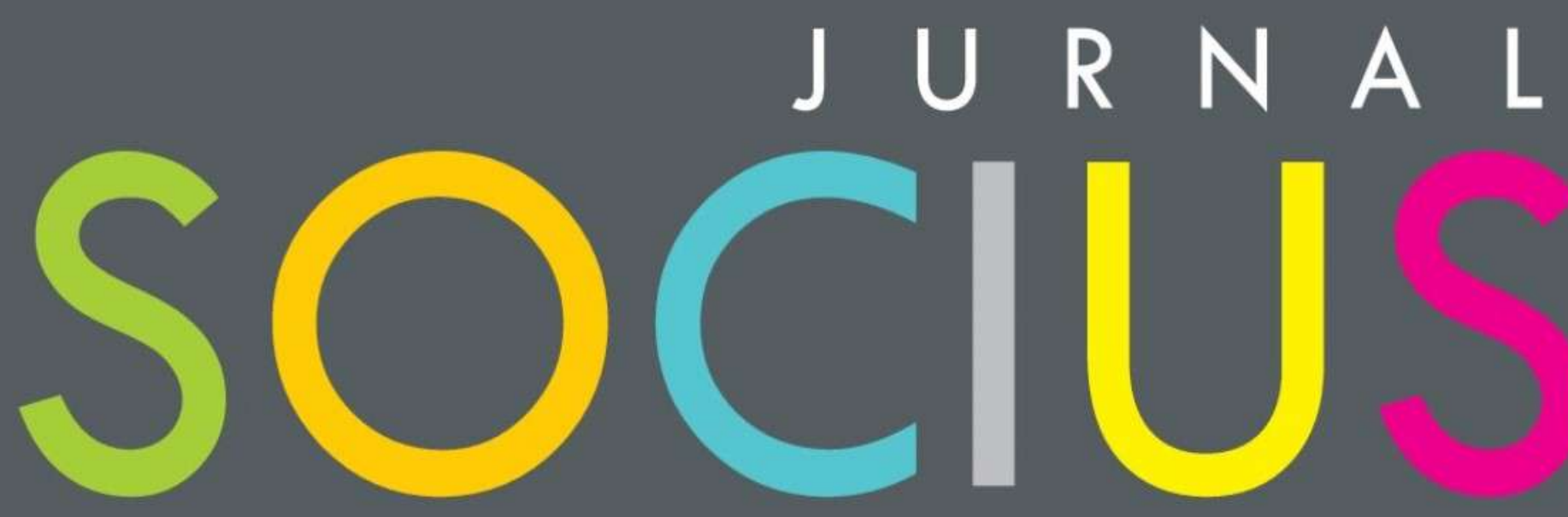

Journal of Sociology Research and Education

DITERBITKAN OLEH :

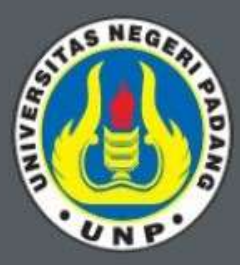

LABOR JURUSAN SOSIOLOGI FAKULTAS ILMU SOSIAL UNIVERSITAS NEGERI PADANG

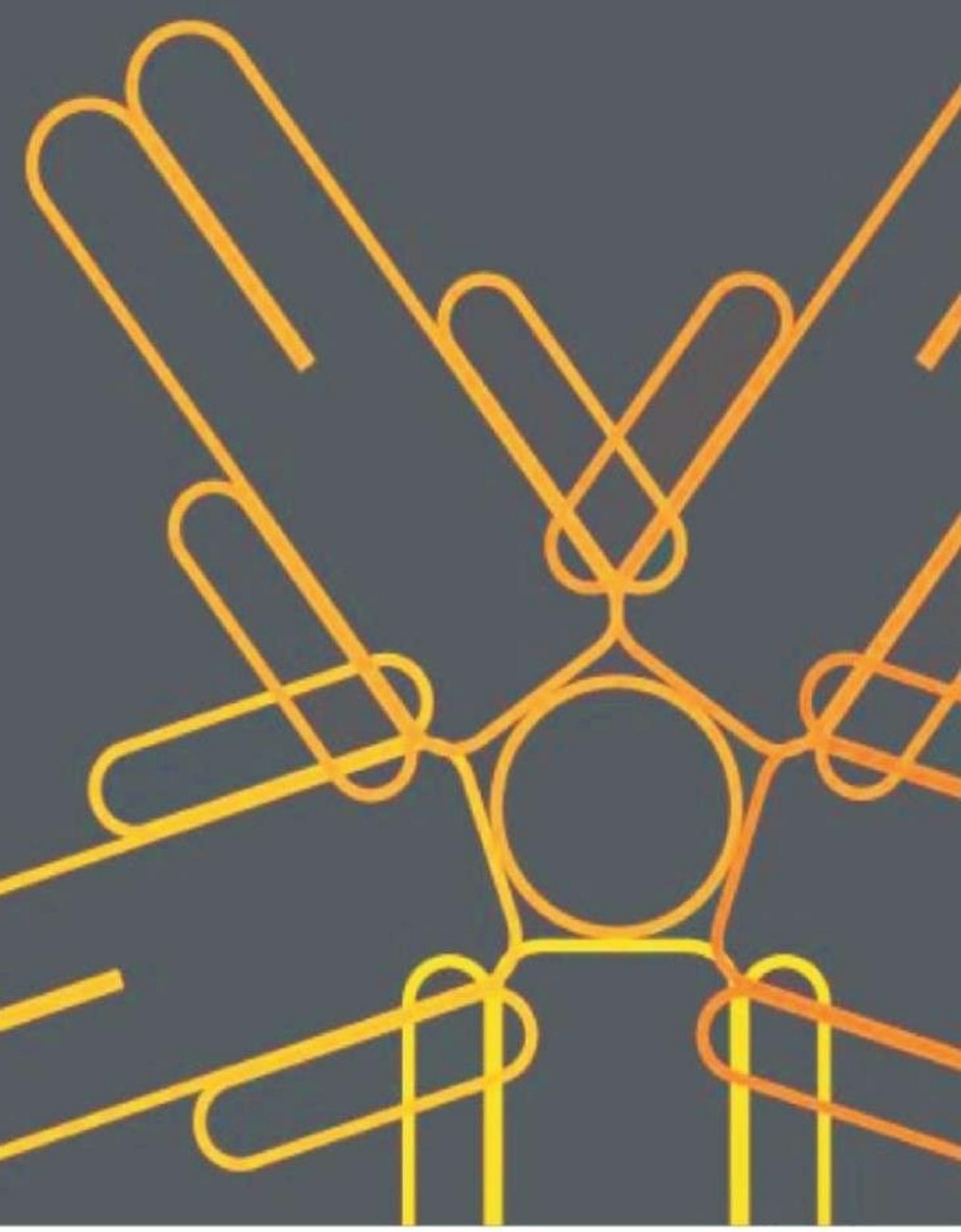




\section{SOCIUS}

Vol. 4, No.1, Th. 2017

ISSN: 2356-4180 (cetak)

2442-8663 (online)

REDAKSI JURNAL SOCIUS

Ketua Dewan Penyunting : Dr. Erianjoni, S.Sos., M.Si

Wakil Ketua Dewan Penyunting : Selinaswati, S.Sos., M.A., Ph.D.

\section{Dewan Penasehat:} Prof. Dr. Syafri Anwar, M.Pd (Universitas Negeri Padang) Prof. Dr. Mestika Zed, MA. (Universitas Negeri Padang) Prof. Dasman Lanin, M.Pd., Ph. D. (Universitas Negeri Padang) Bakhrul Khair Amal, SE.,M.Si. (Universitas Negeri Medan)

Prof. Dr. Ferdinand Kerebungu, M.Si. (Universitas Negeri Manado) Dr.rer.nat. Nurhadi, S.Ant., M. Hum. (Universitas Negeri Solo)

Drs. Emizal Amri, M.Pd., M.Si. (Universitas Negeri Padang) Adri Febrianto, S.Sos., M.Si. (Universitas Negeri Padang) Drs. Ikhwan, M.Si. (Universitas Negeri Padang)

Dewan Penyunting:

Dr. EkaVidya Putra,S.Sos,.M.Si. Dr. Desy Mardiah,S.Sos.,S.Thi,.M.Si Ike Sylvia, S.IP,.M.Si

M. Isa Gautama,S.Pd,.M.Si. Reno Fernandes, S.Pd.,M.Pd.

\section{Layout Editor:}

Rhavy Ferdyan, S.Pd.

Technical Support:

Rudi Mahesa, A.Md.

Alamat Redaksi:

Jurusan Sosiologi FIS UNP

Jl. Prof.Dr.Hamka

Kampus UNP Air Tawar

e-mail: sosan@fis.unp.ac.id

\section{Penerbit}

Labor Jurusan Sosiologi

Universitas Negeri Padang
Artikel :

\section{DAFTAR ISI}

\section{Eka Vidya Putra}

Money Politics Dalam Penyelengaran Pemilihan Umum

Di Kota Pariaman

Halaman 1-16

Helpi Nelwatri

Upaya Preventif Masalah Kesehatan Reproduksi Remaja Melalui Media Informatif Buku Saku Kespro

Berbasis Budaya Lokal Untuk Orang Tua

Di Kabupaten Lima Puluh Kota

Provinsi Sumatera Barat

Halaman 17-21

\section{Junaidi}

Upaya Meningkatkan Kemampuan Peserta Didik Berpikir Kritis

Melalui Penerapan Srategi Pembelajaran Berbasis Masalah

Pada Pembelajaran Sosiologi Kelas XI IPS 2 SMA Negeri 1 Pariaman Halaman 22-30

Muhammad Hidayat

Problematika Internal Nelayan Tradisional KotaPadang:Studi FaktorFaktor Sosial Budaya Penyebab Kemiskinan

$$
\text { Halaman 31-40 }
$$

Mohammad Isa Gautama

Analisis Framing Pemberitaan Operasi Tangkap Tangan Patrialis Akbar

Di Media Daring Lokal Dan Nasional Halaman 41-49

\section{Nurlizawati}

Perceraian Secara Adat (Cerai Dusun)

Halaman 50-60 


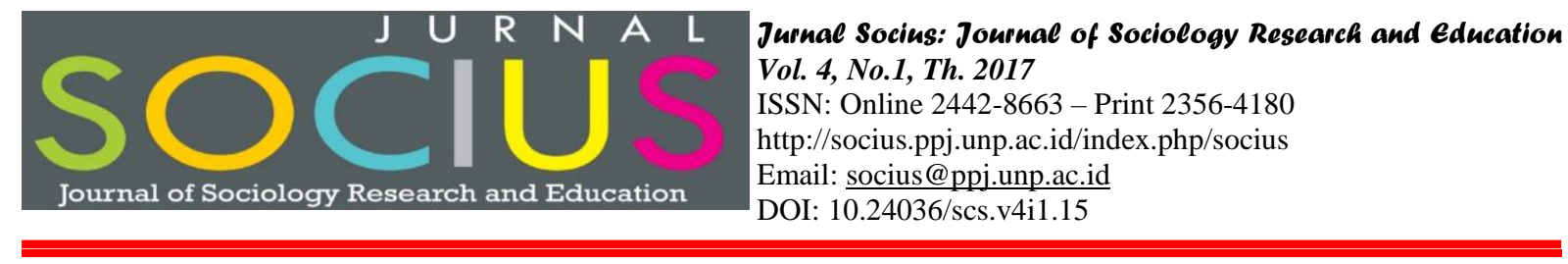

\title{
PROBLEMATIKA INTERNAL NELAYAN TRADISIONAL KOTA PADANG: STUDI FAKTOR-FAKTOR SOSIAL BUDAYA PENYEBAB KEMISKINAN
}

\author{
Muhammad Hidayat \\ Universitas Negeri Padang \\ email: ikanperak08@gmail.com
}

\begin{abstract}
Abstrak
Tulisan ini menjelaskan tentang persoalan keluarga nelayan dalam mempertahankan ekonomi keluarga yang dilakukan oleh Ibu rumah tangga nelayan di kota Padang untuk bertahan hidup dari tekanan sosial-ekonomi. Nelayan miskin di Kota Padang berakar dari faktor komplek, yaitu faktor alamiah dan non alamiah. Perjuangan ibu rumah tangga nelayan miskin dalam bertahan hidup, tidak hanya dipengaruhi oleh etos kerja lingkungan mereka, tetapi juga dipengaruhi oleh kemajuan Kota Padang yang semakin mempertinggi tingkat kesulitan dalam memepertahankan ekonomi keluarga, bahkan penyakit menular yang tidak terdeteksi oleh pemerintah. Kesulitan sosial-ekonomi yang mereka hadapi tersebut, justru menjadikan lebih cerdas untuk mengambil alternatif dengan sumberdaya sosial yang ada disekitar mereka untuk bertahan hidup.
\end{abstract}

Kata kunci: Problematika internal, Nelayan Tradisional, Kemiskinan

\section{Abstract}

This paper describes the problem of family fishermen in maintaining the family economy conducted by housewife housewives in the city of Padang to survive from socio-economic pressure. Poor fishermen in the city of Padang rooted from complex factors, namely natural and non-natural factors. The struggle of the housewives of poor fishermen in survival is not only influenced by their work ethic, but also influenced by the progress of the city of Padang which heightens the level of difficulty in maintaining their family's economy, even infectious diseases that are not detected by the government. The socio-economic difficulties they face, it makes it smarter to take the alternative with the social resources that exist around the brand to survive.

Keywords: Internal problems, Traditional Fishermen, Poverty

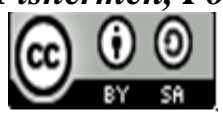

Received: February 6, 2017 Revised: May 10, $2017 \quad$ Available Online: June 22, 2017

\section{Pendahuluan}

$75 \%$ dari wilayah Indonesia merupakan lautan dengan panjang garis pantai $( \pm 95.000$,$\mathrm{km}$ ) dan zona Ekonomi Ekslusif (ZEE) seluas 5.800.000 $\mathrm{Km}^{2}$, dengan potensi hasil periakan sebesar 6,4 juta ton per-tahun, 70\% diantaranya berasal dari perikanan tangkap. Dengan demikian, jika dibandingkan dengan negara-negara lain, maka luas perairan Indonesia merupakan terbesar kedua setelah Amerika Serikat (Sipuk, 2004: 3 ;Kompas, 28/3/2008). Luasnya wilayah perikanan Indonesia dan hasil lautnya yang melimpah belumlah mampu menunjang kehidupan sosial dan ekonomi nelayan ${ }^{1}$ di Indonesia.

\footnotetext{
${ }^{1}$ Anthony T Charles (2001:45) mendefenisikan nelayan sebagai "fisher around the world seems to fit within four principle categories, based on the nature of, and back graound to, their particular fishing activities: Subsistence fishers: those catching fish as thjeir own source of food; Native aboriginal fisher; those belonging to aboriginal group, often fishing for substance; Recreational fisher: those catching fish pricipally for their own
}

Jurnal Socius: Journal of Sociology Research and Education Vol. 4, No.1, Th. 2017

ISSN: Online 2442-8663 - Print 2356-4180 
Secara umum, nelayan di Indonesia dapat diklasifikasikan menjadi dua yakni nelayan tradisional dengan kriteria menggunakan peralatan tradisional, modal usaha yang kecil dan organisasi penangkapan yang relatif sederhana. Nelayan hidup hanya untuk memenuhi kebutuhan sehari-hari dan tidak diinvestasikan untuk pengembangan skala usaha. Kedua adalah nelayan modern dengan kriteria mampu merespon perubahan dan wilayah Indonesia merupakan kawasan over fishing (perairan lebih tangkap) yang dihadapi nelayan. Perbedaan mereka tampak jelas pada keterbatasan penguasaan teknologi, keterbetasan ruang gerak yakni bagian pantai dan bagian tengah lautan (Kusnadi, 2002:86). Persaingan mereka tidak akan pernah dimenangkan oleh nelayan tradisional, sebab kalah dalam penggunaan peralatan yang serba canggih dan kapal besar serta hasil besar dari nelayan modern. Akibat dari semua itu nelayan tradisional tidak pernah keluar dari persoalan kemiskinan ${ }^{2}$. Beberapa contoh nelayan yang termasuk tradisional yaitu nelayan jukung, nelayan pancing, nelayan udang dan nelayan teri nasi.

Ciri-ciri umum dari kehidupan nelayan adalah rendahnya tingkat sosial-ekonomi mereka. Kehidupan mereka setaraf dengan pekerja migran atau setaraf dengan petani kecil (Nigel Smith, 1981:30). Jika dihubunghkan dengan kelompok petani. Nelayan (nelayan buruh dan nelayan kecil atau nelayan tradisional) dikelompokkan menjadi kelompok lapisan sosial paling miskin (Winayu dan Santiasih, 1993: 137). Umumnya petani memiliki pekerjaan sambilan sebagai penghasilan tambahan ketika tiba musim panceklik. Untuk mengisi waktu luang, petani bekerja sambilan seperti membuat kerajinan, beternak, dan pekerjaan nonpertanian.

Faktor-faktor yang bersifat kompleks menyebabkan kemiskinan di kalangan nelayan. Lebih spesifik lagi, Kusnadi (2002:19) menyatakan bahwa kemiskinan yang diderita oleh masyarakat nelayan bersumber dari faktor-faktor sebagai berikut:

“(1) faktor alamiah, yakni berkaitan dengan fluktasi musim-musim penangkapan dan struktur alamiah sumberdaya ekonomi dan; (2) faktor non-alamiah, yakni berhubungan dengan keterbatasan daya jangkau teknologi penangkapan, ketimpangan dalam sistem bagi hasil dan tidak adanya jaminan sosial tenaga kerja yang pasti, lemahnya penguasaan jaringan pemasaran dan belum berfungsinya lembaga koperasi nelayan yang ada serta dampak negatif kebijakan modernisasi perikanan yang telah berlangsung sejak seperempat abad terakhir".

Dengan kata lain dapat diakatakan bahwa faktor kemiskinan di kalangan nelayan dapat sebabkan oleh faktor internal meliputi keterbatasan dibidang pendidikan, kurangnya kesempatan akses teknologi modern dan tidak memiliki modal yang cukup. Faktor lainnya adalah faktor eksternal yaitu terbatasnya potensi sumber daya laut yang bisa dimanfaatkan nelayan, persaingan yang intensif, mekanisme pasar, posisi tawar nelayan yang dihadapi tengkulak, keadaan infrastruktur pelabuhan perikanan, dan yuridiksi otonomi adalah beban yang mempersulit keadaan kemiskinan nelayan tradisional.

Penelitian terdahulu telah membuktikan bahwa persoalan kemiskinan nelayan tradisional merupakan faktor kompleks (Satria, 2002; Suyanto, 2003). Faktor-faktor tersebut tidak hanya berkaitan dengan perubahan cepat pada musim-musim ikan, keterbatasan sumber

enjoyment; Commercial fisher: those catching fish for sale in domestic pr export markets, these fishers are tradistionally viewed as falling into artisanal and industrial categories.

${ }^{2}$ Kemiskinan menurut BPS merupakan suatu kondisi seseorang yang hanya dapat memenuhi makanannya kurang dari 2100 kalori per-kapita per-hari (Tibyan, 2009:2). Sedangakn menurut BKKBN adalah kondisi ketidak mampuan melaksanakan ibadah menurut agamanya, seluruh anggota keluarga; tidak mampu makan dua kali sehari, seluruh anggota keluarga: tidak mampu makan dua kali sehari, seluruh anggota keluarga tidak memiliki pakaian berbeda di rumah, bekerja/ sekolah dan berpergian, bagian terluas rumahnya berlantai tanah, tidak mampu membawa anggota keluarga ke sarana kesehatan. Menurut World Bank merupakan keadaan yang tidak tercpainya kehidupan layak dengan penghasilan adalah 2 USD per-hari (1 USD= Rp. 10.000,-) (Yulianto, 2005: 22).

Jurnal Socius: Journal of Sociology Research and Education Vol. 4, No.1, Th. 2017 
daya manusia, modal serta akses, jaringan perdagangan ikan yang eksploitatif terhadap nelayan sebagai produsen, tetapi juga disebabkan oleh dampak negatif modernisasi perikanan atau revolusi biru yang mendorong terjadinya pengurasan sumberdaya laut secara berlebihan. Proses ini terus berlangsung dan menyebabkan penurunan tingkat pendapatan dan kesulitan memperoleh hasil tangkap. Hasil studi penelitian Kusnadi (2002:26-27) tentang tingkat pendapatan dan sulitnya memperoleh hasil tangkapan di kalangan nelayan tradisional membuktikan bahwa kesenjangan sosial-ekonomi merupakan persoalan krusial yang sulit diahadapi dan tidak mudah diatasi.

Meskipun berbagai program pemerintah telah diluncurkan dalam upaya membantu mereka keluar dari lingkaran kemiskinan seperti: bantuan alat dan kapal perikanan dimulai dari tahun 1980, dana bergulir dimulai pada tahun 1990, bantuan Modal Kerja Masyarakat Pesisir (MKPEMP) di tahun 2000, serta program gerakan pensejahteraan masyarakat pesisir (GEPEMP) yang diprakarsai oleh pemerintah seperti Gubernur, namun kondisi nelayan belum mengalami peningkatan ekonomi. Dengan demikian nelayan merupakan aset strategis yang penting diperhatikan, karena kemiskinan tersebut menjadikan mereka termarginalkan. Walaupun berbagai bantuan telah diluncurkan oleh pemerintah, namun kehidupan masyarakat nelayan tidak banyak mengalami perobahan dari waktu ke waktu.

Dorongan pemerintah di kota Padang dalam upaya percepatan pembangunan di sektor perikanan telah dilakukan pembangunan sarana dan prasarana perikanan seperti: Pelabuhan Samudera Bungus, Pembangunan Industri Perikanan PT. Dempo, dan Fasiltas lainnya seperti PPI (Pusat Pendaratan Ikan) dan TPI (Tempat Pelelangan Ikan) telah dilakukan, namun geliat tersebut masih belum kelihatan. Oleh karena pembangunan yang bersifat sektoral dan terpusat, maka sangat perlu dilakukan penelitian strategi pengentasan kemiskinan dengan perspektif multi dimensi di Kota Padang, baik secara internal maupun eksternal. Dari sebelas Kecamatan di Kota Padang, maka 5 Kecamatan merupakan wilayah yang langsung berbatasan dengan pantai. Berdasarkan data di kota Padang, ditemukan jumlah seluruh nelayan yang berada di sepanjang pantai kota Padang adalah sebagai berikut:

Tabel 1. Jumlah Nelayan di Kawasan Pantai Kota Padang

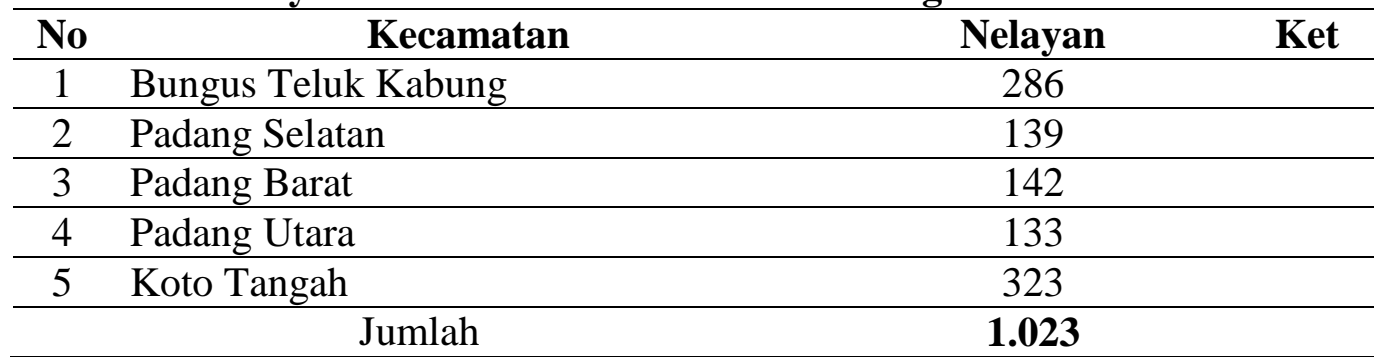

Sumber: Padang dalam angka 2014

Berdasarkan data di atas, dapat diketahui bahwa jumlah nelayan di Kota Padang adalah sebanyak 1.023 jiwa dari jumlah penduduk kota Padang tahun 2014 adalah 876.678 jiwa.

Kondisi ekonomi nelayan yang miskin di kota Padang berpengaruh terhadap gizi keluarga, kesehatan keluarga, perubutan sumber daya perikanan menciptakan kontestasi dan konflik terbuka, pembakaran kapal trawl, dan kesenjangan ekonomi yang semakin tajam justru semakin memperparah kemiskinan nelayan tradisional di Kota. Hebatnya persaingan ekonomi dan perangkap kemiskinan di kalangan nelayan tradisional

Berkaitan dengan uraian di atas maka penting untuk mendiskripsikan dan menganalisis faktor penyebab kemiskinan yang terjadi pada masyarakat nelayan tradisional di kota, seperti kota Padang. Hal tersebut diharapkan dapat mengungkapkan kendala-kendala yang dihadapi nelayan tradisional dalam upaya peningkatan ekonomi nelayan tradisional. 
Masalah kemiskinan di kalangan nelayan tradisional di Kota Padang merupakan masalah yang sulit untuk diselesaikan. Kota Padang merupakan kawasan pesisir yang terdapat di Provinsi Sumatera Barat. Perairan kota Padang merupakan kawasan over fishing (perairan lebih tangkap). Oleh karena itu idealnya keadaan nelayan tradisional Kota Padang harusnya lebih sejahtera, bukan hidup miskin. Hasil penelitian Junaidi (1991) dan (2008) terhadap pembangunan tempat pelelangan ikan di Kota Padang hasil penelitian menunjukkan bahwa TPI hanya tempat memungut retribusi saja manfaat langsung tidak dirasakan oleh masyarakat. Hasil penelitian Junaidi (1992) terhadap paket bantuan alat tangkap di Desa Malilimok di Kepulauan Mentawai menunjukkan bahwa setelah bantuan di berikan dan hasil tangkap meningkat namun terkendala dengan pemasaran, hal ini tidak member pengaruh terhadap kehidupan mereka. Kemajuan teknologi penangkapan ikan dengan menggunakan alat tangkap puse seine (pukat cincin) di Air Bangis mampu meningkatkan produksi hasil tangkapan, namun akibat kekurang infrastruktur seperti kekurang es, air bersih, tidak adanya cold storage, dan kendala pemasaran, kemajuan teknologi juga tidak membawa pengaruh terhadap masyarakat nelayan (Junaidi,1992).

Lemahnya sumberdaya manusia di wilayah pesisir terutama nelayan skala kecil menyebabkan perekonomian mereka sulit untuk berkembang, sehingga kehidupan masyarakat di wilayah pesisir identik dengan masyarakat miskin, kondisi seperti ini merupakan tangtangan bagi program pembangunan pedesaan di wilayah pesisir. Kemiskinan yang dihadapi oleh nelayan merupakan kemiskinan structural, pendapatan sebagai nelayan tidak dapat dipastikan, karena sangat tergantung kepada teknologi dan juga kondisi cuaca yang sangat mempengaruhi operasional penangkapan ikan. Disamping itu peluang pengembangan usaha ekonomi di luar sektor perikanan sulit untuk dilakukan karena terbatasnya pemilikan lahan untuk pengembangan usaha. Kondisi social ekonomi seperti ini menyebabkan masyarakat di wilayah pesisir pasarah dengan pendapatan yang mereka peroleh dan mereka tidak mempunyai masa depan yang jelas. Oleh karena itu penelitian ini mencoba mengkaji strategi pengentasan kemiskinan di tinjau dari perspektif multi dimensi di Kota Padang.

Adapun rumusan masalah dalam penelitian ini adalah sebagai berikut: bagaimana permasalahan internal nelayan tradisional Kota Padang berdasarkan faktor-faktor sosial budaya penyebab kemiskinan?. Tulisan yang terkait dengan Kemiskinan Nelayan telah banyak dilakukan oleh peneliti, beberapa tulisan terkait dengan kemiskinan nelayan diantaranya adalah Mashuri (1996) Menyisir Pantai Utara: Usaha Perekonomian Nelayan di Jawa dan Madura 1850-1940, buku ini menggunakan perspektif historis pada masa kolonial. Penjabarannya hal tersebut terjadi pada nelayan di Jawa dan Madura yang meliputi perkembangan penangkapan ikan, kebijakan pemerintah, perubahan institusi, input ekonomi regional (terutama Siam dan Jepang) dan mempertimbangkan perkembangan lokal seperti usaha perikanan dan organisasi penangkapan ikan, masyarakat nelayan dan sistem sewa, dan maju-mundurnya sektor penangkapan ikan.

Kusnadi (2002) Konflik Sosial Nelayan: Kemiskinan dan Perebutan Sumber Daya Perikanan. Buku ini mengidentifikasi persoalan yang belum dapat terpecahkan di kalangan nelayan begitu juga melalui strategi kebijakan pembangunan yang dirancang pemerintah. Berdasarkan persoalan yang banyak tersebut, Kusnadi menilai pembangunan yang dilakukan pemerintah selama ini masih bersifat "memarginalkan komunitas laut", menyebabkan nasib yang kurang baik berlangsung di kalangan nelayan di seluruh pesisir Nusantara. Tulisan ini juga mengajak pembaca untuk merenungkan kembali potensi sumber daya alam maritim Indonesia yang kaya, apabila dikelola dengan baik maka dapat mewujudkan cita-cita nasional melalui komitmen kebijakan yang jelas dan berkesinambungan dalam mengelola sumber daya kemaritiman masyarakat pesisir. Perbedaannya dengan tulisan ini adalah buku ini tidak 
menjelaskan wilayah penelitiannya dilakukan di kota Padang, tetapi dilakukan di Pasuruan, Pantai Utara Jawa Timur, dan Perairan Selat Madura.

Tulisan lainnya adalah tulisan Sidarta Pujiraharjo (2005 dalam jurnal Antropologi Tahun VI, Nomor 10, Juli-Desember 2005), Tulisan ini bertujuan untuk menjelaskan beragam program yang tidak berjalan lancar dalam mengangkat kesejahteran kelompok masyarakat pantai. Pendekatan penulis dalam tulisan ini adalah menguji model dinamis (Model Ford) yang dipakai dalam meningkatkan kesejahteraan masyarakat nelayan di Kecamatan Koto Tangah Kota Padang.

\section{Metode Penelitian}

Metode penelitian dalam penelitian ini adalah metode deskriptif kualitatif dengan menggunakan data primer dan sekunder dalam mengidentifikasi permasalahan internal nelayan tradisional Kota Padang berdasarkan faktor-faktor sosial budaya penyebab kemiskinan. Menurut Nawawi (1993:87) menyatakan bahwa diskriptif kualitatif merupakan salah satu teknik penggambaran atau lukisan keadaan subyek atau obyek penelitian berdasarkan fakta-fakta yang tampak sebagai mana adanya. Diskripsi menganai data bertujuan mengemukakan gejala-gejala secara lengkap agar permasalahan lebih tampak jelas.

Informan dalam penelitian ini terdiri dari informan kunci (Key informan) dan informan biasa. Informan kunci terdiri dari 5 orang nelayan tradisional kota Padang, sedangkan informan biasa terdiri dari 95 orang nelayan tradisional, istri nelayan, aparat desa, serta penjual ikan di kota Padang. Teknik pengumpulan data digunakan beberapa tahap yaitu tahap observasi, wawancara, dokumentasi dan anlisis data. Tahap kemudian baru dilaksanakan reduksi dan penyajian data berdasarkan permasalahn kajian ini. Pengumpulan data dalam penelitian ini dilakukan pada bulan April 2015.

\section{Hasil dan Pembahasan}

\section{Kondisi Nelayan Kota Padang}

Nelayan tradisional Kota Padang yang menjadi informan penelitian ini berasal dari; 26 orang dari Kecamatan Koto Tangah, 12 orang dari Kecamatan Padang Barat, 12 orang dari Kecamatan Padang Utara, 28 orang dari Kecamatan Bungus Teluk Kabung, 6 orang dari Kecamatan Selatan, 11 orang dari kecamatan Padang Selatan.

Nelayan tradisional umumnya memiliki ciri-ciri yang sama yaitu dari keseluruhan nelayan yang menjadi Informan penelitian ini, mereka berumur 24 tahun hingga 66 tahun. Dari 95 informan biasa; 55 orang merupakan tamatan SD atau setingkat SD, 30 orang merupakan tamatan SMP atau setingkat SMP, dan 10 orang merupakan tamatan SMA atau setingkat SMA. Untuk bekal bekerja sebagai nelayan, latar belakang pendidikan seseorang memang tidak penting. Artinya pekerjaan nelayan merupakan pekerjaan kasar yang bergantung pada otot dan pengalaman kerja, maka tingkatan pendidikan tidak dianggap berpengaruh dengan kehidupan nelayan.

Menurut Kusnadi (2002:30) pendidikan di kalangan nelayan menjadi penting ketika mereka mengganti jenis pekerjaan mereka kepada jenis pekerjaan lain. Dengan pendidikan mereka yang rendah, kondisi ini akan selalu mempersulit nelayan tradisional ke pada bidang kerja lain.

Berdasarkan rata-rata penghasilan mereka dalam sekali melaut adalah Rp.93.513,- perhari. Hal ini terkait dengan teknologi penangkapan ikan yang mereka gunakan masih mengguakan peralatan tradisional, berikut penggunaan jenis alat tangkap mereka; 17 orang menggunakan jaring insang, 8 orang menggunakan jaring udang, 33 orang menggunakan pukat tepi/ payang, 8 orang mengguanakan jaring udang, 5 orang menggunakan pancing 
colok, 17 orang menggunakan Gill net, 2 orang menggunakan pancing dan 5 orang menggunakan pancing ulur.

Berdasarkan jumlah anak, nelayan tradisional kota Padang rata-rata memiliki 3 - 4 orang anak pada setiap keluarga. Artinya anak merupakan tanggungan ekonomi bagi setiap nelayan. Bagi nelayan tradisonal anak menunjukkan salah satu investasi tenaga kerja dalam mengembangkan ekonomi keluarga mereka. Meskipun beratnya beban ekonomi nelayan dengan banyaknya tanggungan ekonomi keluarga, Namun umumnya seluruh anggota kelurga nelayan merupakan pekerja di bidang nelayan, Seperti istri dan anak. Hal ini dilihat dari beberapa sumber modal turun atau bantuan modal tambahan ke laut dari nelayan di kota Padang berasal dari istrinya dan anaknya. Umumnya mereka meminjam modal ke pada teman dan keluarga.

Nelayan tradisional di kota Padang sangat bersaing dengan nelayan yang menggunakan perahu motor untuk mencari ikan. Nelayan yang menggunakan motor biasanya dikategorikan menjadi nelayan modern, modernitas saat ini mengalami pergeseran, modernitas tidak hanya menggunakan perahu motor, melainkan pada besar atau kecilnya motor perahu yang digunakan serta tingkat kemampuan penangkapan ikan dalam mengekploitasi ikan sendiri.

Berdasarkan kepemilikan motor dan harga perahu mereka dapat diketahui dari 95 orang adalah; 47 orang menggunakan perahu motor seharga 7-8 juta rupiah, kemudian 33 orang dengan perahu seharga 10-20 juta rupiah, 5 orang menggunakan perahu seharga 5 juta rupiah, 3 orang menggunakan perahu dengan harga 4 juta rupiah, 2 orang menggunakan perahu seharga 1- 2 juta rupiah, 1 orang menggunakan perahu seharga 50 juta rupiah, dan 3 orang hanya bekerja sebagai awak kapal.

Berdasarkan jumlah dan penggunaan jenis alat tangkap nelayan di kota Padang dapat diketahui sebanyak; 41 orang menggunakan pukat tepi/ payang, 17 orang menggunakan jaring insang, 17 orang menggunakan gillnet, 8 orang menggunakan jaring udang, 5 orang menggunakan pancing colok, 5 orang mengguanakn pancing ukur, dan 2 orang menggunakan pancing. Selain itu jika dihubungkan dengan jarak tangkap atau panjang alat nelayan kota Padang dapat diketahui bahwa: 53 orang memiliki panjang alat yang dipakai $100 \mathrm{~m}-200 \mathrm{~m}$, 35 orang memiliki panjang alat yang dipakai 300m $-400 \mathrm{~m}, 6$ orang memiliki alat tangkap $500 \mathrm{~m}-600 \mathrm{~m}, 1$ orang me,iliki panjang alat tangkap $10 \mathrm{~m}-50 \mathrm{~m}$.

Berdasarkan rata-rata income yang didapatkan per-hari dari nelayan tradisional di kota Padang; 64 orang memiliki pendapatan Rp.100.000,- sampai Rp. 300.00,-, 15 orang dengan penghasilan Rp.400.000,- sampai Rp.600.000,-, 16 orang yang menjelaskan penghasilan mereka tidak menentu (Rp.50.000,- sampai Rp.400.000,-). Jika dihubungkan dengan keuntungan nelayan tradisional di kota Padang, umumnya mereka mendapatkan keuntungan rata-rata Rp. 150.000,- sa,pai Rp.200.000,-, tapi sebelum dikeluarkan biaya melaut dan biaya Rumah Tangga.

Berdasarkan data temuan kepemilikan motor perahu dan jenis alat tangkap, dapat diketahui bahwa perahu motor yang digunakan nelayan di kota Padang dapat dikategorikan masih tradisional, karena keterbatasan kemampuan alat tangkapnya dalam melaut, sehingga hanya mampu menghasilkan jumlah ikan yang sedikit. Umunya mereka menggunakan alat tangkap seharga 7-8 juta rupiah, yang hanya memiliki kemampuan menjelajah sampai perairan pantai, dan tidak ada yang memilki teknologi penangkapan ikan dengan kemampuan jelajah sampai di lepas pantai (off shore).

Dapat diketahui bahwa ekonomi nelayan tradisional di kota Padang tergolong minim dan pas-pasan. Kondisi ini menuntut sebagian kecil nelayan tradisonal di Kota Padang untuk mencari pekerjaan sampingan atau tambahan untuk memenuhi kebutuhan keluarganya. Berdasarkan pekerjaan sampingan yang dimilikinya, dari 95 orang nelayan tradisional hanya 5 orang yang memiliki kebun dan sawah dengan jenis tanaman kelapa, coklat dan tanaman 
sayur-sayuran. Sedangkan nelayan tradisional yang lainnya sama sekali tidak punya pekerjaan tambahan.

Peran perempuan sebagai Ibu rumah tangga nelayan menjadi lebih penting bagi kelangsungan ekonomi keluarga nelayan. Berdasarkan kebutuhan bantuan dari istri dalam melaut, diungkapkan 61 orang membutuhkan bantuan istri, 28 orang tidak membutuhkan bantuan istri dan 6 orang lagi belum menikah. Jika dilihat penghasilan istri per-hari dari nelayan tradisional di kota Padang dapat dikemukan; 38 orang memiliki penghasilan Rp.30.000,- sampai Rp.50.000,-. 7 orang berpenghasilan Rp. 60.000,- sampai Rp.100.000,dan 50 orang berpenghasilan tidak menentu atau bekerja tidak tentu.

Ragam pekerjaan yang dimasuki oleh istri nelayan tradisional di kota Padang dilakukan juga dengan pengumpulan kerang-kerang, pengolahan hasil ikan, pembersihan perahu/ kapal yang baru mendarat, pengumpul anak ikan, pekerja di perusahan udang atau industri ikan, pembuat jaring, pedagang ikan eceran, pedagang ikan perantara, peternak, berkebun, dan pemilik warung. Penghasilan yang diperoleh guna menambah keuangan keluarga karena tingkat pendapatan suami belum mencukupi dalam pemenuhan kebutah sehari-hari. Dalam rumah tangga nelayan miskin peran perempuan sangat signifikan. Perempuan-perempuan yang terlibat dalam aktivitas mencari nafkah demi kelangsungan keluarga (Kusnadi, 2002, $34)$.

Selain istri, anak-anak nelayan memiliki keterlibatan dan pembagian kerja yang jelas dalam kegiatan peningkatan penghasilan keluarga. Anak laki-laki akan bekerja mengikuti orang tuanya atau kerabatnya mencari ikan ke laut atau membersihkan perahu yang baru tiba dari melaut. Anak perempuan, disamping membantu kegiatan domestik orang tuanya, juga membantu ibunya bekerja di industri-industri pengolahan ikan atau bekerja berjualan di warung-warung kecil. Potensi ekonomi anak-anak tersebut sangat membantu pemenuhan kebutuhan sehari-hari rumah tangga nelayan tradisional.

Dalam masyarakat nelayan tradisional kota Padang juga ditemukan lembaga-lembaga kelompok nelayan seperti kelompok nelayan Robin Mandiri, dan kelompok nelayan Madta. Kelompok nelayan ini yang paling diikuti adalah lembaga yang memiliki peranan dalam simpan pinja (simpanan). Dari 95 orang nelayan tradisional kota Padang, 45 orang merupakan nelayan yang ikut sebagai anggota lembaga tersebut, sedangkan 50 orang nelayan lainnya atau lebih dari separuh nelayan tidak mengikuti lembaga tersebut. Umumnya sifat lembaga yang lebih digandrungi nelayan tradisional ini adalah lembaga yang sederhan, fleksibel, dan adaptif terhadap kondisi sosial-ekonomi lokal, serta diikuti oleh istri nelayan.

Hasil tabungan nelayan tersebut biasanya diberikan setahun sekali, terutama menjelang hari lebaran Idul Fitri, dapat berupa uang kontan atau bahan-bahan konsumsi. Simpanan dilakukan pada saat nelayan memiliki uang yang mencukupi. Pengelola tabungan mendatangi anggota simpanan setiap hari untuk menabung dengan kempuan keuangan yang dimilikinya. Dari 95 orang nelayan tradisional di kota Padang, dapat diketahui bahwa 9 orang mereka memiliki tabungan tersendiri dan 86 orang tidak memiliki tabungan. Hal ini tidak tertutup kemungkinan adanya tabungan dari kalangan istri nelayan sendiri di sekita tempat mereka menetap.

Pentingnya strategi yang digunakan nelayan tradisional di kota Padang dalam menanggulangi kemiskinan dan kelangsungan hidup umumnya, mereka tinggal secara terpola di keluarga batih, hubungan personal antar anggota kerabat sangat erat kaitannya dalam ketahanan hidup mereka.Menurut Peter von Blackkenburg dan Reinhold Sachs,menyatakan bahwa keluarga miskin memfungsikan kerbat tidak hanya untuk mensosialisisasikan anak, tetapi kerabat berfungsi sebagai kelompok primer yang menopang dan memberikan jaminan sosial ekonomi bagi anggota kerabatnya. Masalahnya adalah berapa kemampuan masyarakat terus, mempertahankan kehidupan komunal diantara kehidupan yang serba komersial?. 


\section{Kultur Nelayan Tradisional}

Aspek kultural mengenai maslah kemisinan di kalangan nelayan tradisional di Kota Padang disebabkan oleh aspek internal masyarakat bersangkutan yang berkaiatan dengan nilai-niali atau pandangan hidup dan kebiasaan hidup. Gambaran tentang Kultur Nelayan pada masyarakat nelayan tradisional di Kota Padang dapat dijelaskan berdasarkan:

1. Kebiasaan dan pola hidup masyarakat

Bagi masyarakat nelayan tradisional di Kota Padang, aktivitas menangkap ikan merupakan mata pencarian yang bersifat turun temurun sebagai penghidupan ekonomi keluarga. Aktivitas nelayan tradisional di kota Padang sangat dipengaruhi oleh keadaan geografis. Di samping itu, nelayan tradisional di kota Padang memandang pendapatan mereka dapatkan dari usaha melaut hanya untuk pemenuhan kebutuhan sehari-hari. Mereka bekerja menurut kebiasaan mereka sehari-hari. Apabila cuaca baik, akan mulai melaut. Dengan kebiasaan berangkat pagi sesudah subuh, malam harinya mereka dapat beristirahat. Siangnya mereka dapat memperbaiki jaring mereka di waktu luang. Pagi dan sore mereka dapat menjual ikan di tepi pantai atau ke pasar.

Kebiasaan yang berkembang di kalangan masyarakat nelayan adalah judi dan minum beralkohol. Perilaku ini sudah berkembang lama sejak dulu, jika dulu mereka terbiasa minum dengan minuman tradisional, tapi kini telah berubah pada minuman modern. Kebiasaan ini telah terpola dan terorganisir. Sebagian nelayan tradisional di Kota Padang, pandangan mereka telah mulai berubah mengenai "takdir tuhan atau jalan hidup mereka berada pada usaha mereka", dulu memang sikap mereka banyak menganut faham bahwa "takdir atau jalan hidup mereka telah digariskan oleh Tuhan". Kebiasaan ini menunjukkan adanya sebagian kebiasaan yang masih dipertahankan dan sebagaian lagi telah mengalami perubahan.

2. Nilai-nilai Melaut

Umumnya nelayan di Kota Padang tradisional digolongkan menjadi nelayan tradisional, terutama berdasarkan jenis alat tangkap dan kemampuan alat tangkap dan jarak penangkapan ikan dari pantai yang dapat dikatakan masih tradisional. Nilai-nilai yang mereka pahami dipengaruhi oleh keadaan alam yang keras dan penuh tantangan, serta menuntut penyesuaian nelayan dengan alam dan beranganggapan bahwa keberuntungan dan kesengsaraan sebagai bagian dari hidup. Mereka sangat menghargai adat-istiadat yang terkait dengan penangkapan ikan secara turun-temurun. Meskipun nilai-nilai tersebut secara ekonomi tidak menguntungkan dan bahkan tidak rasional atau masuk akal, meskipun pemahaman tersebut menghambat kreativitas dan inovasi untuk maju. Nelayan tradisional di kota Padang masih mempercayai adanya nilai-nilai; perempuan tidak boleh melaut, tidak boleh melaut siang hari Jum'at, berkata kotor sedang melaut, tidak melaut ketika badai, menunjuk benda-benda yang tidak di kenal sewaktu melaut, dilarang berbuat macam-macam (mesum), dan dilarang takabur.

Selain memahami nilai-nilai yang mereka pahami secara turun temurun, nilai-nilai hidup yang bersifat konsumtif diwaktu penghasilan ikan mereka banyak, terlihat dari banyaknya barang-barang yang dapat mereka beli, namun pada saat panceklik, mereka menyadari pentingnya uang simpanan dan keutamaan barang-barang yang bersifat primer.

3. Diversifikasi Pekerjaan

Menghadapi penghasilan yang tidak pasti bagi nelayan tradisional di kota Padang menuntut pengaturan waktu bagi kalangan nelayan. Salah satunya adalah dengan mengkombinasikan kerja, seperti pagi melaut, siangnya mereka bekerja di bidang lain seperti bidang pertanian, berburu, berdagan dan lainnya. Bahkan sulit menentukan mana pekerjaan utama di kalangan Nelayan tradisional tersebut. Hal ini disebakan karena pekerjaan menangkap ikan selalu berpindah-pindah tempat, dari satu jenis penangkapan (metode peralatan tangkap) ke jenis penangkapan ikan lain.Meskipun dari uraian di atas jumlah 
mereka sedikit di bidang pertanian dan perkebunan di kota Padang, namun tidak tertutup kemungkinan di bidang jasa dan perdagangan di sekitar pantai atau tempat mereka menetap.

Waktu yang dipakai sebagai pilihan kerja baru bagi belayan tradisional relatif singkat, karena hal ini bertujuan untuk menghadi masa-masa kritis atau musim yang sulit, sehingga sulit dihandalkan dalam pemenuhan kebutuhan subsitensi mereka. Meskipun mereka berkerja sampingan, namun dalam waktu singkat mereka akan kembali, sebab kemampuan mereka yang terbatas di bidang lain dan hanya ahli di bidang kelautan. Upaya ini merupakan pilihan yang rasional. Pilihan pekerjaan di kalangan nelayan juga memiliki pembagian yang jelas. Artinya adaya pandangan tentang perbedaan pekerjaan perempuan dan pekerjaan laki-laki nelayan.

\section{Penutup}

Berdasarkan temuan permasalahan dalam penelitin ini yaitu faktor-faktor internal penyebab kemiskinan di kalangan nelayan tradisional yang berada di kota, tidaklah terdapat perbedaan dengan wilayah pedesaan, yaitu; berpendidikan rendah, keterampilan sedikit di luar perikanan, miskin, memiliki modal yang sedikit dalam mengembangkan sektor pertanian. Kondisi internal lainnya ditunjukkan pada nelayan yang tidak mempunyai modal, dan tidak memiliki teknologi dan keterampilan dalam peningkatan hasil nelayannya.

Kemiskinan di kalangan komunitas Nelayan tradisonal kemiskinan dilatar belakangi oleh keterbasan dalam penguasaan sumber daya ekonomi, rendahnya tingkat pendidikan, kondisi alam yang kurang bersahabat. Disamping itu, faktor penyebab kemiskinan juga dipengaruhi oleh budaya berupa kebiasaan hidup berdasarkan nilai-nilai sosial yang ada

\section{Daftar Pustaka}

BPS. (2014). Monitoring dan Kajian terhadap Program Kemiskinan di Indonesia. Jakarta

Charles, Anthony T. (2001). Suitainable Fishery System, Fish and Aquatic Resources Series. Oxford: Blackwell Science.

Junaidi. (1991). Tempat Pelelangan Ikan Masalah dan Pengembangannya di Kota Padang. Padang: UBH Press.

.(1992). Dampak Bantuan Paket Teknologi Penangkapan Ikan Terhadap Nelayan Tradisional di Kepulauan Mentawai (Studi Kasus di Desa Malilimok Kec. Siberut Selatan Kab. Padang Pariaman. Padang: UBH Press.

...(2008). The Implementation of Auction System on The Price of Tuna Fish in West Sumatera. International Conference 2008 on Quantitative Method Used in Economic and Business at University Malahayaty Lampung. Padang: UBH Press.

Kompas, 28 Maret 2008

Kusnadi. (2002). Polemik Kemiskinan Nelayan. Yogyakarta: Pondok Edukasi dan Pokja Pembaruan

Nawawi.(1993). Metode Penelitian Bidang Sosial. Yogyakarta: Gajah Mada University Press.

Satria, Arif. (2002). Dinamika Modernisasi Perikanan: Formasi Sosial dan Mobilitas Nelayan. Bandung HUP 
Suyanto, Bagong. (2003). Kajian Model Pemberdayaan Ekonomi Rakyat di Desa Pantai Madura dan kawasan Selatan Jawa Timur. Surabaya: Lemlit UNAIR Jatim.

Sipuk. (2004). Penangkapan Iklan di Laut, Aspek Produksi. SIPUK

Smith, Nigel. (1981). Man, Fish, and the Amazone. New York: Colombia University Press.

Winayu dan Santiasih. (1993). Permasalahan Pembangunan Perikanan. Dalam Mubyarto (dkk). Riau dalam Kancah Perubahan Ekonomi Global. Yogyakarta: Aditya Media

Yulianto, Trimo. (2005). Tesis "Fenomena Program- Program Pengentasan Kemiskinan di Kabupaten Klaten”. Yogyakarta: Perpustakaan UGM. 